\title{
Tópicos Especiais de Educação Matemática Financeira
}

\author{
João Socorro Pinheiro Ferreira Áurea Rodrigues Borges \\ Colegiado de Licenciatura em Matemática, UNIFAP \\ 68.903-419, Macapá, AP \\ E-mail: joaoferreira@unifap.br aureborges2010@hotmail.com
}

\begin{abstract}
$\underline{\text { RESUMO }}$
Esse trabalho partiu do pressuposto de que o estudo da Educação Matemática Financeira faz-se necessária à formação acadêmica do estudante de licenciatura em Matemática, considerando-se que cada vez mais as pessoas estão acessando ao mercado financeiro, para ter acesso às linhas de crédito disponível ao consumidor. Para que este texto se concretizasse, realizou-se uma pesquisa bibliográfica as obras de autores que ressaltam importância da Matemática Financeira. É discutido o surgimento dos juros, a partir dos primeiros registros feitos pelos babilônios até suas aplicações atualmente. Discutiuse sobre a educação matemática financeira através de suas aplicações no cotidiano. Também apresentaremos uma pesquisa de campo, que foi realizada em quatro lojas comerciais de Macapá (capital do estado do Amapá), nas quais se percebe que essa comercialização produtos, são variáveis de mesma marca ou diversificadas, porém com valores e taxas de juros distintas. No decorrer do trabalho, observou-se que a educação matemática financeira tem várias vertentes, como por exemplo: comercial, empresarial, financeira e administrativa, que foram analisadas associadas ao nosso convívio social. Também mostraremos uma metodologia de ensino dessa área da Matemática através do uso de tecnologia digital: calculadora HP $12 \mathrm{C}$ e da planilha eletrônica Excel. Sendo assim, conclui-se é de grande relevância esse fragmento da Matemática para a vida cotidiana. As encontrarmos em todas as aplicações comerciais e financeiras, que vão desde compras de um produto supérfluo até o mais necessitado. Ou nos juros das taxa de impostos que pagamos, seja nos contracheque ou outras situações problemas que nos cercam.
\end{abstract}

Palavra-chaves: Educação Matemática Financeira. Ensino e aprendizagem. Juros Simples e Compostos. Sistemas de Amortização.

\section{Referências}

[1] ASSAF NETO, Alexandre. Matemática financeira e suas aplicações. 6. ed. São Paulo: Atlas, 2001.

[2] BOYER, Carl Benjamin. História da Matemática. São Paulo: Edgard Blucher, 1974. (Tradução: Elza F. Gomide.)

[3] BRASIL. Ministério da Previdência Social. Tabela de contribuição dos segurados empregados, empregado doméstico e trabalhador avulso, para pagamento de remuneração. Disponível em: http://www.mps.gov.br. Acesso em: 24 Jan. 2013.

[4] BRASIL. Receita Federal do Brasil. Imposto de Renda de Pessoa Física. Disponível em: < http://www.receita.fazenda.gov.br/aliquotas/TabProgressiva2012a2015.htm.> Acesso em: 06 Nov. 2012.

[5] CIÊNCIAS ATUARIAIS. In: WIKIP_EDIA, a enciclopédia livre. Flórida: Wikimedia Foundation, 2012. Disponível em: $\langle$ http : ==pt: wikipedia:org=w=index:php?title $=$ Ci\%C3\%AAncias atuariais\&oldid $=30552592>$. Acesso em: 21 Mar. 2013. 
[6] COELHO, José Coelho. Programa para o Cálculo da Interpolação de Lagrange. Disponível em: < http : = = professor: ucg: $\mathrm{br}=$ site Docente $=$ admin $=$ arquivosUpload=5021=material=LFATrabalhoPratico:pdf Acesso em: 21 Mar. 2013.

[7] EVES, Howard. Introdução à história da matemática. Campinas, SP: Editora da UNICAMP, 2004. (Tradução: Hygino H. Domingues)

[8] IEZZI, Gelson; HAZZAN, Samuel; DEGENSZAJN, David Mauro. Fundamentos de matemática elementar 11 : Matemática Comercial, Matemática Financeira e Estatística Descritiva. 1 ed. São Paulo: Atual, 2004.

[9] KUHNEN, Osmar Leonardo. Finanças Empresariais. 2. ed. São Paulo: Atlas, 2008.

[10] MARTINS, Eliseu; ASSAF NETO, Alexandre. Administração Financeira: As finanças das empresas sob condições inflacionárias. 1. ed. São Paulo: Atlas, 1986.

[11] MORGADO, Augusto Cesar; WAGNER, Eduardo; ZANI, Sheila Cristina. Progressões e Matemática Financeira. 4. ed. Rio de Janeiro: SBM, 2001. (Coleção do Professor de Matemática).

[12] PARENTE, Eduardo Afonso de Medeiros. Matemática comercial e financeira. ed. reform. São Paulo: FTD, 1996. 